P-ISSN 2442-6636

E-ISSN 2355-3987

www.ijhn.ub.ac.id

Artikel Hasil Penelitian

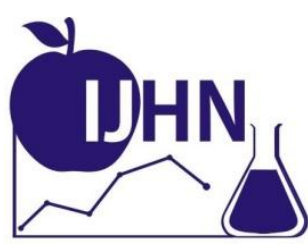

\title{
Hubungan Komposisi Tubuh dengan Kepadatan Tulang Wanita Usia Subur di Kota Bandung
}

\author{
Laras Ristati Eka Widyanti ${ }^{1 *}$, Inggita Kusumastuty ${ }^{1}$, Eva Putri Arfiani ${ }^{1}$ \\ ${ }^{1}$ Program Studi Ilmu Gizi Fakultas Kedokteran Universitas Brawijaya Malang \\ *Alamat korespondensi, e-mail: larasristatieka@yahoo.co.id
}

\begin{abstract}
Abstrak
Osteoporosis merupakan salah satu masalah kesehatan karena dapat mengakibatkan berkurangnya kualitas hidup dan kematian. Salah satu faktor yang dapat mempengaruhi kepadatan tulang diantaranya yaitu komposisi tubuh. Komposisi tubuh seseorang terbagi menjadi total lemak tubuh dan lean mass. Beberapa penelitian menyatakan bahwa komposisi tubuh berhubungan dengan kepadatan tulang, namun masih memiliki kesimpulan berbeda antar peneliti. Tujuan penelitian ini adalah untuk mengetahui hubungan antara komposisi tubuh dan kepadatan tulang wanita usia subur di Kota Bandung. Penelitian ini menggunakan pendekatan cross sectional dengan jumlah responden 70 orang yang dipilih menggunakan metode purposive sampling. Pada penelitian ini didapatkan rata-rata usia responden adalah 37 tahun dengan status gizi yang normal namun memiliki lemak tubuh dalam kategori obesitas. Mayoritas kepadatan tulang responden termasuk dalam kategori osteopenia. Berdasarkan uji korelasi Pearson dan regresi menyatakan bahwa ada hubungan positif antara total lemak tubuh dengan kepadatan tulang ( $p$-value 0,006$)$ dengan keeratan $(0,327)$ serta ada hubungan negatif antara lean mass dan kepadatan tulang $(0,006)$ dengan keeratan $(-0,328)$. Kesimpulan dalam penelitian ini adalah semakin tinggi lemak tubuh seseorang maka memiliki resiko lebih rendah terkena osteoporosis, akan tetapi menjaga lemak tubuh dengan kategori normal akan menghindarkan dari penyakit yang berhubungan dengan kelebihan berat badan seperti jantung, diabetes melitus sehingga disarankan kepada responden untuk tetap menjaga total lemak tubuh dan berat badan dalam katagori normal.
\end{abstract}

Kata kunci: kepadatan tulang, komposisi tubuh, total lemak tubuh, lean mass

\begin{abstract}
Osteoporosis is one of health problems that can lead to reduced life quality and death. Body composition is one of factors that affect bone density. Body composition is divided into total body fat and lean mass. Some studies suggest that body composition is associated to bone density, but some researchers have different conclusions. This study aims to determine the relationship between body composition and bone density of women of reproductive age in Bandung. This study used cross sectional approach with a total sample of 70 respondents selected using purposive sampling method. In this study, the average age of respondents obtained was 37 years with normal nutritional status but had body fat in obesity category. The majority of bone density of respondents was under osteopenia category. Based on Pearson correlation test and regression test, there was a positive relationship between total body fat with bone density (p-value 0.006) with low closeness of
\end{abstract}


variable (0.327), but there is a negative relationship between lean mass and bone density (0.006) with low closeness of variable (-0.328). This study concludes that the higher the body fat of a person, the lower the risk of osteoporosis. However, maintaining normal body fat will prevent diseases associated with overweight such as heart disease and diabetes mellitus, so the respondents are suggested to keep the total body fat and body weight in normal category.

Keywords: bone density, body composition, total body fat, lean mass

\section{PENDAHULUAN}

Osteoporosis merupakan kondisi tulang menjadi keropos, yang memiliki sifat yang khas berupa berkurangnya massa tulang [1]. Hasil penelitian Puslitbang Gizi Departemen Kesehatan Republik Indonesia pada 16 propinsi menemukan risiko osteoporosis di Indonesia tahun 2005 mencapai 10,3\%. [1]. Provinsi Jawa Barat memiliki prevalensi risiko osteoporosis lebih besar $(22,2 \%)$ dibandingkan angka prevalensi nasional $(10,3 \%)$ [1].

Dasar terjadinya osteoporosis adalah ketidakseimbangan antara reabsopsi tulang dengan formasi tulang. Apabila penghancuran lebih banyak daripada pembentukan tulang akan menjadi keropos. Banyak faktor yang dapat memengaruhi timbulnya osteoporosis seperti genetik atau keturunan, usia, kurang aktifitas fisik, postur tubuh, komposisi tubuh (indeks massa tubuh, lean body mass, total lemak dalam tubuh) [1]. Faktor lain yang menjadi faktor terjadinya osteoporosis adalah menopause, riwayat patah tulang, adanya penyakit seperti tiroid, diabetes melitus, kanker hati, ginjal, usus, pola makan, stres, polusi bahan kimia, gaya hidup tidak sehat misalnya kebiasaan merokok, minum alkohol, asupan makanan seperti kalsium, vitamin $\mathrm{D}$, protein, garam, dan konsumsi obat thyroid, steroid, GNRH agonist, diuretik, dan antasid [1].

Wanita memiliki risiko penurunan massa tulang lebih cepat dibandingkan pria. Penurunan massa tulang pada wanita dapat disebabkan oleh berkurangnya produksi hormon estrogen pada wanita menopause yang membuat peningkatan penghancuran tulang oleh sel osteoklas dan penurunan pembentukan tulang oleh sel osteoblas [3]. Menurut International Osteoporosis Foundation, jumlah kejadian fraktur osteoporosis per tahun pada wanita lebih dari 45 tahun menyebabkan lebih lama mendapatkan perawatan di rumah sakit dibandingkan penyakit serangan jantung, stroke, dan kanker [4].

Usia antara 20 sampai 49 tahun termasuk dalam usia produktif bagi wanita. Pada usia ini wanita masih mendapatkan menstruasi secara teratur yang disebut usia subur. Pada fase ini diharapkan wanita lebih waspada pada penyakit yang akan muncul ketika usia setelah menopause dengan cara menjaga kondisi badan dengan prima dan bugar [5].

Salah satu faktor risiko osteoporosis pada wanita adalah komposisi tubuh. Komposisi tubuh adalah proporsi relatif antara jaringan lemak dan jaringan tanpa lemak [6]. Komposisi tubuh terdiri dari dua bagian yaitu simpanan lemak (jaringan adipose) dan jaringan bebas lemak (lean tissue). Jaringan bebas lemak sangat aktif dalam proses metabolisme sehingga kebutuhan gizi seseorang dipengaruhi oleh jaringan ini, sedangkan jaringan adipose berfungsi sebagai cadangan energi [6]. Komposisi tubuh dapat memengaruhi kesehatan tulang seseorang. Menurut penelitian yang dilakukan oleh Namwongprom pada tahun 2012 yang dilakukan di Thailand menyatakan bahwa ada hubungan yang signifikan antara komposisi tubuh dengan kepadatan tulang pada wanita premenopause [7]. Ini sejalan dengan penelitian Gholami yang dilakukan di Iran pada tahun 2013 yang menunjukkan pada subjek wanita post menopause menyatakan bahwa dari parameter komposisi tubuh, massa tubuh tanpa lemak adalah prediktor kuat dari 
osteoporosis [8]. Dengan menggunakan model ini, wanita berisiko terkena osteoporosis dapat diidentifikasi. Penelitian Farida pada tahun 2012 di Pontianak menyimpulkan bahwa ada korelasi positif antara persen lemak tubuh dengan kepadatan tulang, sedangkan ada korelasi negatif antara jaringan bebas lemak dengan kepadatan tulang pada wanita dewasa 30 sampai 40 tahun [9]. Berdasarkan uraian di atas, peneliti tertarik untuk melakukan penelitian hubungan antara komposisi tubuh dan kepadatan tulang wanita usia subur (WUS) Kota Bandung.

\section{METODE PENELITIAN \\ Rancangan/Desain Penelitian}

Jenis penelitian ini merupakan penelitian kuantitatif dengan desain observasional menggunakan metode crosssectional, yaitu pengukuran variabel independen (komposisi tubuh) dan variabel dependen (kepadatan tulang) dilakukan satu kali dan dalam satu periode waktu. Definisi operational dari komposisi tubuh dibedakan menjadi dua yaitu total lemak tubuh dan lean mass. Komposisi tubuh (total lemak tubuh dan lean mass) diukur dengan cara pengukuran antropo-metri menggunakan alat Omron HBF 306 Logic Pro Body Fat Analyzer. Hasil ukur yang didapatkan berupa persentase lemak tubuh dan lean mass dengan skala numerik. Kepadatan tulang adalah kualitas jaringan tulang yang dilihat dari nilai $T$-Score responden dan dibandingkan dengan nilai kontrol orang muda yang sehat, dengan cara pemeriksaan bone mineral density (BMD) menggunakan alat ukur Achilles Qualitative Ultrasound (QUS). Hasil ukur yang didapatkan berupa nilai T-Score dengan skala numerik.

\section{Sumber Data}

Sumber data dari penelitian ini berdasarkan hasil pengambilan responden yang dilakukan di Giant Suci Kota
Bandung. Penelitian ini dilakukan pada bulan Agustus tahun 2015.

Sumber data terdiri dari data primer. Data primer terdiri dari karakteristik responden, komposisi tubuh (total lemak tubuh dan lean mass), dan nilai kepadatan tulang responden. Karakteristik responden terdiri dari usia, usia, tingkat pendidikan, pekerjaan, kebiasaan minum susu, dan kebiasaan minum kopi responden menggunakan kuesioner identitas diri dengan metode wawancara, sedangkan untuk status gizi responden diperoleh melalui perhitungan hasil pengukuran berat badan dengan alat timbangan injak digital Omron $\mathrm{HN}-283$ dengan ketelitian $0,1 \mathrm{~cm}$ yang telah dikalibrasi dan pengukuran tinggi badan dengan alat microtoice Staturmeter Baroka dengan tinggi maksimum $200 \mathrm{~cm}$ dan ketelitian $0,1 \mathrm{~cm}$ yang telah dikalibrasi.

\section{Sasaran Penelitian \\ (Populasi/Subjek/Subjek Penelitian)}

Responden penelitian diambil dengan menggunakan teknik non probability sampling secara purposive sampling dan diperoleh jumlah minimal responden 67 orang. Jumlah responden yang didapatkan pada penelitian ini adalah sebanyak 70 orang responden. Kriteria inklusi pada penelitian ini adalah (1) subjek wanita usia subur yang berusia antara 15-49 tahun, (2) tidak mengalami cacat di bagian kaki, (3) bersedia untuk terlibat menjadi subjek dalam penelitian. Kriteria eksklusi meliputi: (1) nilai kepadatan tulang respoden tidak terbaca alat saat melakukan pengukuran kepadatan tulang.

\section{Pengembangan Instrumen dan Teknik Pengumpulan Data}

Instrumen yang digunakan pada penelitian ini adalah kuesioner pendahuluan, informed consent, dan kuesioner inti. Kuesioner pendahuluan digunakan untuk memastikan responden yang diambil sebagai subjek penelitian sesuai dengan 
kriteria inklusi. Informed consent digunakan untuk menyatakan persetujuan responden mengikuti penelitian. Penelitian ini dilakukan setelah mendapatkan surat kelaikan etik (ethical clearance) dari komisi etik Universitas Brawijaya dengan nomor 439/EC/KEPK-S1/08/2015.

\section{Teknis Analisis Data}

Analisis data pada penelitian ini terdiri dari analisis univariat dan bivariat. Analisis univariat dalam penelitian ini menggunakan analisis secara deskriptif dengan menggunakan tabel distribusi frekuensi jumlah dan persentase. Analisis ini digunakan untuk menganalisis karakteristik responden meliputi usia, tingkat pendidikan, pekerjaan, kebiasaan minum susu, dan kebiasaan minum kopi responden, menganalisis sebaran data lemak tubuh, lean mass, dan kepadatan tulang responden, sedangkan analisis bivariat dalam penelitian ini menggunakan analisis statistik yang dilakukan untuk mengetahui hubungan antara komposisi tubuh (total lemak tubuh dan lean mass) dengan kepadatan tulang responden menggunakan uji kolerasi pearson dengan nilai signifikansi $\alpha=0,05$.

\section{HASIL PENELITIAN \\ Gambaran Umum Responden}

Distribusi gambaran umum responden disajikan dalam Tabel 1. Berdasarkan Tabel 1 didapatkan sebagian responden besar masuk dalam kategori usia $\geq 40$ tahun. Tingkat pendidikan terbanyak adalah SMA. Mayoritas responden bekerja sebagai ibu rumah tangga. Mayoritas responden masih jarang membiasakan diri untuk minum susu. Mayoritas responden tidak terbiasa mengonsumsi kopi. Mayoritas responden memiliki status gizi dalam kategori normal.

\section{Komposisi Tubuh}

Rerata lemak tubuh responden adalah $29,08 \%( \pm 5,86 \%)$. Mayoritas responden memiliki lemak tubuh dalam katagori gemuk. Rerata lean mass responden adalah $70,91 \%( \pm 5,86 \%)$.

\section{Kepadatan Tulang}

Rata-rata kepadatan tulang responden adalah -1,20 ( $\pm 0,94 S D)$. Mayoritas responden memiliki kepadatan tulang dalam kategori osteopenia.

\section{HASIL PENELITIAN}

\section{Hubungan Lemak Tubuh dengan Kepadatan Tulang}

Variabel yang dihubungkan pada penelitian ini adalah total lemak tubuh dengan kepadatan tulang. Dalam penelitian menunjukan hasil uji statistik antara total lemak tubuh dan kepadatan tulang menunjukan ada hubungan yang bermakna ditandai dengan nilai $p$-value $0,006(\mathrm{p}<0,05)$ dengan tingkat keeratan hubungan sebesar 0,327 (tingkat keeratan rendah). Korelasi bernilai positif sehingga semakin tinggi total lemak tubuh maka semakin tinggi nilai kepadatan tulang.

\section{Hubungan Lean mass dengan Kepadatan Tulang}

Variabel yang dihubungkan pada penelitian ini adalah dengan kepadatan tulang. Dalam penelitian menunjukan hasil uji statistik antara lean mass dan kepadatan tulang menunjukan ada hubungan yang bermakna ditandai dengan nilai $\mathrm{p}$-value $0,006 \quad(\mathrm{p}<0,05)$ dengan tingkat keeratan hubungan sebesar $-0,328$ (tingkat keeratan rendah). Korelasi bernilai negatif sehingga semakin tinggi total lean mass maka semakin rendah nilai kepadatan tulang. 
Tabel 1. Karakteristik Responden

\begin{tabular}{|c|c|c|}
\hline Karakteristik & $\mathrm{N}$ & $\%$ \\
\hline \multicolumn{3}{|l|}{ Usia (tahun) } \\
\hline$<40$ tahun & 29 & 41,4 \\
\hline$>40$ tahun & 41 & 58,6 \\
\hline \multicolumn{3}{|l|}{ Tingkat Pendidikan } \\
\hline SD & 1 & 1,4 \\
\hline SMP & 6 & 8,6 \\
\hline SMA & 33 & 47,1 \\
\hline Perguruan Tinggi & 30 & 42,9 \\
\hline \multicolumn{3}{|l|}{ Pekerjaan } \\
\hline Ibu Rumah Tangga & 36 & 51,4 \\
\hline PNS & 5 & 7,1 \\
\hline Wiraswasta & 8 & 11,4 \\
\hline Mahasiswa & 5 & 7,1 \\
\hline Pegawai Swasta & 16 & 22,9 \\
\hline \multicolumn{3}{|l|}{ Kebiasaan Minum Susu } \\
\hline Tidak & 42 & 60 \\
\hline 1 gelas & 23 & 21,9 \\
\hline$\geq 2$ gelas & 5 & 7,1 \\
\hline \multicolumn{3}{|l|}{ Kebiasaan Minum Kopi } \\
\hline Tidak & 42 & 60 \\
\hline 1 gelas & 15 & 21,4 \\
\hline 2 gelas & 9 & 12,9 \\
\hline$\geq 3$ gelas & 4 & 5,7 \\
\hline \multicolumn{3}{|l|}{ Status Gizi } \\
\hline Underweight & 9 & 12,9 \\
\hline Normal & 34 & 48,6 \\
\hline Overweight & 12 & 17,1 \\
\hline Obesitas 1 & 13 & 18,6 \\
\hline Obesitas 2 & 2 & 2,9 \\
\hline
\end{tabular}

Tabel 2. Distribusi Lemak Tubuh Responden

\begin{tabular}{lccc}
\hline & Lemak Tubuh & (n) & $(\%)$ \\
\hline Kurus & 1 & 1,4 \\
Normal/Optimal & 15 & 21,4 \\
Sedikit Gemuk & 12 & 17,1 \\
Gemuk & 24 & 34,4 \\
Obesitas & 18 & 25,7 \\
\hline & Jumlah & 70 & 100 \\
\hline
\end{tabular}

Tabel 3. Distibusi Kepadatan Tulang Responden

\begin{tabular}{lccc}
\hline & Kepadatan Tulang & $(\mathrm{n})$ & $(\%)$ \\
\hline & Normal & 22 & 31,4 \\
Osteopenia & & 46 & 65,7 \\
Osteoporosis & & 2 & 2,9 \\
\hline & Jumlah & 70 & 100 \\
\hline
\end{tabular}




\section{PEMBAHASAN}

\section{Karakteristik Responden}

Rerata usia responden adalah 37 tahun. Bertambahnya usia sejalan dengan peningkatan resiko osteoporosis. Menurut penelitian yang dilakukan $\mathrm{Pi}$ YZ menyatakan bahwa pada usia > 40 tahun akan dimulai penurunan massa tulang dan akan terus berlanjut hingga akhir kehidupan [10]. Selain itu, bertambahnya usia osteoblast dalam sumsum tulang akan digantikan oleh sel lemak sehingga terjadi penurunan volume tulang trabecular di sumsum tulang sehingga akan terjadi penurunan massa tulang [11].

Hasil distribusi tingkat pendidikan responden menunjukkan bahwa sebagian besar tingkat pendidikan responden adalah tamatan SMA. Tingkat pendidikan merupakan salah satu faktor yang menentukan seseorang memperoleh informasi khususnya informasi mengenai kesehatan. Oleh karena itu seseorang yang memiliki tingkat pendidikan yang lebih tinggi akan lebih mudah dan memahami informasi kesehatan dibandingkan dengan yang memiliki tingkat pendidikan yang lebih rendah [12].

Hasil distribusi status pekerjaan pada penelitian ini sebagian besar adalah ibu rumah tangga. Status pekerjaan berhubungan dengan tingkat aktifitas responden setiap harinya. Menurut penelitian yang dilakukan Widyanti pada tahun 2013 menyatakan bahwa rata-rata aktifitas ibu rumah tangga bila dibandingkan dengan IPAQ (Internasional Physical Activity Quesionnaire) termasuk dalam kategori aktifitas fisik ringan karena ibu rumah tangga kebanyakan jarang menyempatkan diri berolah raga dan aktivitas yang sering dilakukan adalah tidur dan duduk [13].

Sebagian besar responden belum terbiasa mengkonsumsi susu setiap harinya. Susu merupakan salah satu sumber bahan makanan yang tinggi kalsium. Kalsium dibutuhkan dalam proses mine- ralisasi tulang sehingga dapat menurunkan risiko kehilangan massa tulang [14].

Sebagian besar responden memiliki status gizi normal. Status gizi merupakan salah satu yang dapat memengaruhi kepadatan tulang. Hal ini sesuai dengan penelitian Widyanti pada tahun 2013 yang menyatakan bahwa semakin tinggi nilai status gizi seseorang maka semakin tinggi pula nilai kepadatan tulangnya namun hal tersebut terjadi bila status gizi masih dalam katagori normal dan diimbangi dengan aktifitas fisik yang cukup aktif [13]. Hal ini disebabkan oleh pertumbuhan tulang akan semakin meningkat membentuk sel-sel apabila ditekan oleh bobot yang berat dan indeks massa tubuh menunjukkan efek protektif terhadap osteoporosis primer [15].

\section{Lemak Tubuh}

Rerata lemak tubuh responden adalah 29,08\%. Mayoritas responden memiliki total lemak tubuh dengan kategori gemuk. Peningkatan lemak tubuh terjadi secara konsisten dari usia 25 sampai 65 tahun, yaitu $17 \%$ menjadi $29 \%$ pada pria dan $29 \%$ menjadi $38 \%$ pada wanita. Lemak tubuh seseorang dapat dipengaruhi oleh asupan energi, aktifitas fisik dan proses bertambahan usia serta dipengaruhi juga oleh suatu penyakit [16].

\section{Lean mass}

Berdasarkan hasil perhitungan lean mass yang didapatkan melalui hasil akhir pengurangan antara berat tubuh dengan lemak tubuh responden. didapatkan ratarata lean mass responden adalah 70,91\%. Komponen tubuh yang terkandung dalam lean mass adalah air, protein, cairan intra dan ekstraseluler, otot, organ-organ vital, komponen-komponen protein dari sel-sel adipose dan tulang [16].

Lean mass pada wanita memiliki risiko penurunan lebih besar dibandingkan dengan pria. Penurunan ini dapat disebabkan oleh perubahan hormonal dan gaya 
hidup. Hormon yang memengaruhi adalah growth hormone dan hormon steroid [16].

\section{Kepadatan Tulang}

Rerata kepadatan tulang responden adalah $-1,20$. Setelah dibandingan dengan standar kepadatan tulang menurut Kemenkes tahun 2008, sebagian besar responden dalam kategori osteopenia [17]. Kepadatan tulang dapat dipengaruhi oleh beberapa faktor diantaranya adalah faktor individu seperti usia, ras, jenis kelamin, status menopause, riwayat osteoporosis keluarga, paritas (riwayat mengandung dan melahirkan). Faktor gaya hidup seseorang pun dapat memengaruhi kepadatan tulang seperti kebiasaan merokok, konsumsi alkohol, aktifitas fisik, dan aktifitas olahraga [18]. Dampak yang ditimbulkan bila kepadatan tulang terus menurun adalah risiko patah tulang meskipun tidak ada trauma yang hebat, melainkan hanya terjatuh, mengangkat beban, mendorong, dan trauma ringan [1].

\section{Hubungan Total Lemak Tubuh dengan Kepadatan Tulang}

Berdasarkan uji statistik yang dilakukan pada penelitian ini, didapatkan hasil bahwa terdapat hubungan positif antara total lemak tubuh dengan kepadatan tulang. Hal tersebut sesuai dengan penelitian yang dilakukan oleh Ho-Pham dan Nguyen pada tahun 2014 yang menyatakan bahwa ada hubungan yang antara lemak tubuh dan kepadatan tulang dengan nilai $(\mathrm{p}=0,03<0,05)$ dengan kekuatan korelasi ( $\mathrm{r}=0.31)$ [19]. Penelitian Ho-Pham sejalan dengan penelitian yang dilakukan oleh Faraswati pada tahun 2008 di Yogyakarta menyatakan bahwa ada hubungan positif persen lemak tubuh dengan bone mineral density dengan nilai $(\mathrm{p}=0,001<0,05)$ dan kekuatan korelasi $(\mathrm{r}=0,468)[20]$.

Studi yang dilakukan Ricci pada tahun 2001 di Denmark mengatakan bahwa terjadi penurunan $4,2 \%$ mineral tulang pada seluruh tubuh dan $4 \%$ di pinggul pada wanita yang melakukan penurunan berat badan dan diet sebesar $5,5 \%$ dari total berat badan selama 6 bulan [21]. Beberapa studi telah menunjukkan bahwa beban mekanis, jaringan adiposity, dan faktor hormonal seperti hormon estrogen adalah salah satu efek perlindungan dari lemak terhadap kepadatan tulang [22].

Efek perlindungan lemak terhadap kepadatan tulang adalah memberikan beban mekanis pada tulang. Pada keadaan yang normal tulang melakukan remodeling karena tulang merupakan jaringan yang dinamik. Remodeling tulang terjadi karena adanya perubahan hormonal dan pembebanan mekanik. Remodeling unit merupakan unit yang mengatur keseimbangan antara sel osteoblast dan osteoklas. Jika tulang mendapatkan beban mekanik maka tulang akan mengalami sres mekanik dan dapat menimbulkan efek pembentukan jaringan tulang lebih cepat dan menurunkan bone turn over yang mengurangi penyerapan tulang. Dengan demikian pembebanan mekanik dapat memperbaiki ukuran, bentuk, dan kekuatan tulang [23].

Lemak tubuh dapat membantu dalam memproduksi hormon estrogen [22]. Estrogen merupakan hormon seks steroid yang berfungsi penting untuk metabolisme tulang, hormon ini mengatur sel osteoblast dan osteoklas serta menjaga keseimbangan dari pembentukan dan penghancuran tulang. Hal ini dapat disebabkan karena sel osteoblast memiliki reseptor estrogen alpha dan betha (ER $\alpha$ dan ER $\beta$ ) di dalam sitosol. Dalam diferensiasinya sel osteoblast mengekspresikan reseptor betha (ER $\beta) 10$ kali lipat dari reseptor estrogen alpha (Er $\alpha)$ [24]. Menurut penelitian yang dilakukan Kyong et al. menyatakan bahwa peningkatan hormon estrogen dapat meningkatkan nilai kepadatan tulang seseorang [25].

Berbeda dari penelitian Ho-Pham dan Faraswati, menurut penelitian yang 
dilakukan oleh Liu et al. pada tahun 2014 menyatakan bahwa efek protektif lemak berlaku untuk responden di bawah usia 50 tahun, karena pada usia lebih dari 50 tahun keseimbangan hormon telah terganggu dan peningkatan lemak tubuh secara signifikan. Dalam penelitian tersebut juga menyatakan bahwa apabila jumlah lemak tubuh $33-38 \%$ atau $22-40$ $\mathrm{kg}$ lemak tubuh maka termasuk dalam katagori yang membahayakan kesehatan [26].

Penelian lain yang dilakukan oleh Cao menyatakan bahwa lemak tidak selalu memberikan efek yang positif terhadap kepadatan tulang, namun ada beberapa penelitian yang menyatakan bahwa lemak berdampak negatif terhadap kepadatan tulang. Efek negatif kelebihan lemak tubuh terhadap osteoporosis dapat dijelaskan dalam mekanisme berikut yang mendukung hasil bahwa kelebihan lemak tubuh khususnya pada lemak viseral merupakan faktor risiko osteoporosis. Obesitas sentral terkait dengan peradangan kronis, meningkatnya jaringan sitokin proinflamasi yang beredar pada orang yang kelebihan lemak dapat meningkatkan aktivitas osteoklas dan penyerapan tulang. Sekresi leptin yang berlebihan dan atau penurunan produksi adinopektin oleh adiposit pada orang yang kelebihan lemak dapat secara langsung memengaruhi pembentukan tulang atau secara tidak langsung mempengaruhi penyerapan tulang. Asupan tinggi lemak yang sering menyebabkan penumpukan lemak, dapat mengganggu penyerapan kalsium usus, sehingga menurunkan ketersediaan kalsium untuk pembentukan tulang [27]. Perbedaan hasil dalam penelitian Liu dengan hasil penelitian Faraswati dan HoPham dapat disebabkan oleh perbedaan alat ukur dan algoritma nilai standar lemak tubuh seperti alat Fat Monitoring, Norland, dual Xray dan BIA, bisa disebabkan pula oleh perbedaan T-Score populasi yang dipilih [28].

\section{Hubungan Total Lean mass Tubuh dengan Kepadatan Tulang}

Berdasarkan uji statistik yang dilakukan pada penelitian ini, didapatkan hasil bahwa terdapat hubungan negatif antara total lean mass dengan kepadatan tulang. Hal tersebut sesuai dengan penelitian yang dilakukan oleh Ho-Pham dan Nguyen pada tahun 2014 yang menyatakan bahwa ada hubungan yang signifikan antara lean mass dan kepadatan tulang dengan nilai $(\mathrm{p}=0,026<0,05)$ dengan kekuatan korelasi $(\mathrm{r}=-0,36)$ [19]. Penelitian ini sejalan dengan penelitian yang dilakukan Farida pada tahun 2012 di Pontianak menyatakan bahwa adanya hubungan negatif antara lean mass dengan kepadatan tulang dengan nilai $\mathrm{p}=0,004$ $(\mathrm{p}<0,05)$ dengan kekuatan korelasi $(\mathrm{r}=-0,4)$ [9].

Berbeda dengan pernyataan yang dilakukan oleh Liu et al. tahun 2013 menyatakan bahwa lean mass merupakan prediktor positif dengan kepadatan tulang dominan tubuh. Studi ini menyatakan bahwa peran otot yang merupakan salah satu unsur dari lean mass dapat memberikan beban statis pada tulang dan peningkatan lemak tubuh dengan kenaikan berat badan dapat mengurangi dampak dari lean mass terhadap kepadatan tulang [26].

Perbedaan hasil tersebut dengan hasil penelitian ini, dapat disebabkan oleh studi dilakukan pada jumlah subjek yang diamati kelompok usia [19]. Selain faktor tersebut ras dan etnis juga merupakan faktor yang dapat menyebabkan perbedaan hasil dari penelitian ini karena ras dan etnis merupakan penentu peting struktur tubuh seseorang [29]. Jumlah subjek dalam satu penelitian sangat mempengaruhi hasil dalam penelitian tersebut, menurut Ho-Pham dan Nguyen subjek ideal dalam penelitian ini sebaiknya lebih dari 300 orang subjek untuk lebih menggambarkan efek lean mass terhadap kepadatan tulang [19]. 


\section{Implikasi Hasil Penelitian terhadap Bidang Gizi Kesehatan}

Hasil penelitian ini menujukkan bahwa ada hubungan positif antara total lemak tubuh dengan kepadatan tulang responden, sehingga semakin tinggi total lemak tubuh maka semakin tinggi pula kepadatan tulang., akan tetapi menjaga lemak tubuh dengan kategori normal akan menghindarkan dari penyakit yang berhubungan dengan kelebihan berat badan seperti jantung, diabetes melitus sehingga disarankan kepada responden untuk tetap menjaga total lemak tubuh dan berat badan dalam katagori normal. Kepadatan tulang bukan hanya dipengaruhi oleh komposisi tubuh, namun masih banyak faktor seperti asupan makan dan aktifitas fisik. Sehingga ahli gizi dapat menyarankan kepada masyarakat bahwa asupan yang seimbang dan olah raga yang teratur dapat meningkatkan kepadatan tulang lebih baik dibandingkan dengan pengaruh lemak tubuh terhadap kepadatan tulang.

\section{Keterbatasan Penelitian}

Penelitian ini memiliki alat untuk mengukur kepadatan tulang adalah qualitative ultrasound yang hanya dapat mengukur gambaran kepadatan tulang keseluruhan badan sehingga tidak dapat melihat kepadatan tulang setiap bagian tubuh. Alat pengukur lemak tubuh hanya menggunakan BIA sehingga hanya melihat lemak tubuh secara keseluruhan tanpa melihat setiap bagian tubuh lainnya.

\section{SIMPULAN}

Berdasarkan hasil penelitian yang telah dilakukan dapat disimpulkan bahwa terdapat hubungan yang positif antara lemak tubuh dan kepadatan tulang dan terdapat pula hubungan negatif antara lean mass dengan kepadatan tulang.

\section{SARAN}

Peneliti berharap adanya penelitian lebih lanjut dengan menggunakan case control atau uji perbedaan berdasarkan usia sehingga pengaruh komposisi tubuh dapat telihat lebih jelas bila dibandingkan dengan kepadatan tulang dan alat pengukuran kepadatan tulang lebih baik menggunakan DEXA, sehingga akan lebih tergambar pengaruh komposisi tubuh di setiap kepadatan tulang seluruh bagian tubuh.

\section{UCAPAN TERIMA KASIH}

Ucapan terima kasih disampaikan khususnya pada PT. Anlene Fontera yang membantu dalam pemerikasaan kepadatan tulang responden dan kepada Giant Suci Kota Bandung atas ketersediaannya menerima penulis untuk melaksanakan penelitian di tempat tersebut.

\section{DAFTAR RUJUKAN}

1. Tandra H. Segala sesuatu yang Harus Anda Ketahui Tentang Osteoporosis: Mengenal, Mengatasi,dan Mencegah Tulang Keropos. Jakarta: PT. Gramedia Pustaka Utama; 2009. 5-37.

2. Departemen Kesehatan. Surat Keputusan Menteri Kesehatan Republik Indonesia Nomor 1142/Menkes/Sk/XII/2008 tentang Pedoman Pengedalian Osteoporosis. Jakarta: Departemen Kesehatan; 2008.

3. Buana R. Upaya Pencegahan Osteoporosis Pada Wanita Usia Produktif (20-45 Tahun) di Poli Penyakit Dalam Rumah Sakit Umum Pusat H. Adam Malik Medan. Skripsi. Medan: Fakultas Keperawatan Universitas Sumatra Utara; 2010.

4. IOF. Osteoporosis Fact Sheet. Switzerland: International Osteoporosis Foundation; 2010.

5. Departemen Kesehatan. Profil Kesehatan Indonesia. Jakarta: Departemen Kesehatan; 2011.

6. Gibney M, Margaretts BM, Kearney JM, Arab L. Gizi Kesehatan Masyrakat. Jakarta: Penerbit Buku Kedokteran EGC; 2005. 406-409. 
7. Namwongprom. Effect of Fat Mass and Lean Body Mass on Bone Mineral Density in Postmenapousal and Perimenoupausal Thai Women. International Jurnal of Women's Health. 2013; 5 (1): 87-92.

8. Gholami M, Ghassembaglaou N, Nikbakh H, Eslamian F. The Relationship Between Body Composition and Osteoporosis in Postmenopausal Women. Departement of Physical Edication and Sport Science and Resesarch Branch. Islamic Azad University. 2013; 10 (4): 55-64.

9. Farida H. Hubungan Indeks Massa Tubuh dan Komposisi Tubuh dengan Densitas Massa Tulang Wanita Dewasa di Perwatusi Kota Pontianak. Tesis. Yogyakarta: Universitas Gadjah Mada; 2012.

10. Pi YZ, Wu XP, Liu SP, Cao XZ. Agerelated Changes in Bone Biochemical and Their Relationship with Bone Mineral Density in Normal Chinese Women. Journal of Bone and Mineral Metabolism. 2006; 24 (5): 380-385.

11. Rosen CJ, Bouxsein ML. Mekanisms of Desease: is Osteoporosis the Obesity of Bone. Jurnal Natural Practice Rhematologi. 2006; 2 (1): 35 43.

12. Hardayati YA. Faktor-Faktor yang Berhubungan dengan Perilaku Pencegahan Osteoporosis pada Wanita Premenopause di Komplek Kartika Sejahtera Blok J Rw 06 Sasak Panjang, Bogor 2012. Artikel Ilmiah. Jakarta: Program Studi Keperawatan Sekolah Tinggi Ilmu Kesehatan Sint Carolus; 2013.

13. Widyanti LRE. Hubungan Asupan Protein Hewani, Aktifitas Fisik, Indeks Massa Tubuh dan Kepadatan Tulang di Kelurahan Cisaranten Wetan Kota Bandung. Karya Tulis Ilmiah. Bandung: Jurusan Gizi Poltekkes Kemenkes; 2013.
14. Noor Z, Sumitro SB, Hidayat M, Rahim AH, Sabarudin A, Umemura T. Atomic Mineral Characteristics of Indonesian Osteoporosis by HighResolution Inductively Coupled Plasma Mass Spectrometry. Scientific World Journal. 2012; 10 (6): 11001106.

15. Groff JL and Gropper SS. Advanced Nutrition and Human Metabolism. United State: Wadsworth Thomson Leaming; 2000. 526-531.

16. Asiah N. Perubahan Komposisi Tubuh pada Lanjut Usia. Skripsi. Jakarta: Fakultas Kedokteran Universitas Yasri; 2013.

17. Kementerian Kesehatan. Pedoman Pengendalian Osteoporosis. Jakarta: Departemen Kesehatan; 2008. 3-11.

18. Noviana M. Asupan Zat Gizi, Aktifitas Fisik, dan Kepadatan Tulang Penari. Skripsi. Semarang: Fakultas Kedokteran Universitas Dipenogoro; 2011.

19. Ho-Pham and Nguyen. Association Between Lean Mass, Fat Mass, and Bone Mineral Density: A MetaAnalysis. The Journal of Clinical Endocrinologi and Metabolism. 2014; 99 (1): 8-30.

20. Faraswati NF. Hubungan Komposisi Tubuh dengan Bone Mineral Density (BMD) pada Pasien Rawat Jalan RS Dr. Sardjito Yogyakarta. Tesis. Yogyakarta: Program Studi Ilmu Gizi. Universitas Gadjah Mada; 2008.

21. Ricci T. Moderate Energy Restriction Increases Bone Resorption in Obese Postmenopausal Women. The American Journal of Clinical Nutrition. 2001: 73 (2): 347-352.

22. Zhao, Liu YJ, Hamilton J, Recker RR, Deng HW. Relationship of Obesity with Osteoporosis. Jurnal. The Journal of Clinical Endocrinology and Metabolism. 2011; 92 (5): 1640-1646.

23. Liswati H. Kombinasi Latihan Fisik dan Pemberian Daun Semanggi Menghambat Peningkatan 
Ketidakseimbangan Proses Remodeling Tulang Perempuan Pascamenopause Melalui Peran Reseptor Estrogen Sel. Disertasi. Surabaya: Program Doktor Program Studi Ilmu Kedokteran Program Pascasarjana Universitas Airlangga; 2007.

24. Bell NH. RANK Ligand and the Regulation of Skeletal Remodeling. J. Clin. Invest. 2003; 111: 1120-1122.

25. Kim KC, Shin DH, Lee SY, Im JA, Lee DC. Relation between Obesity and Bone Mineral Density and Vertebral Fractures in Korean Postmenopausal Women. Yonsei Med. J. 2010; 51 (6): 857-863.

26. Liu PY, Ilich JZ, Brummel-Smith $\mathrm{K}$, Ghosh S. New Insight into Fat, Muscle, and Bone Relationship in Women: Determining the Threshold at Which Body Fat Assumes Negative Relationship with Bone Mineral Density. International Journal of Preventive Medicine. 2007; 5 (11): 1452-1463.

27. Cao J. Effects of Obesity on Bone Metabolism. Journal of Orthopaedic
Surgery and Research. 2011; 6 (1): 630.

28. Gnudi S, Sitta E, Fiumi N. Relationship Between Body Composition and Bone Mineral Density In Women With and Without Osteoporosis: Relative Contribution of Lean and Fat Mass. J Bone Miner Metab. 2007; 25 (5): 326-332.

29. Castro JP, Joseph LA, Shin JJ, Arora SK, Nicasio J, Shatzkes $\mathrm{J}$, et al. Differential Effect of Obesity on Bone Mineral Density in White, Hispanic and African American Women: A Cross Sectional Study. Nutrition \& Metabolism. 2005; 2: 9. 